\title{
Observations on the metazoan parasites of the Atlantic salmon (Salmo salar) after its reintroduction into the Elbe River basin in the Czech Republic
}

\author{
František Moravec \\ Institute of Parasitology, Academy of Sciences of the Czech Republic, Branišovská 31, 37005 České Budějovice, Czech \\ Republic
}

Key words: Atlantic salmon, Salmo salar, reintroduction, helminths, brown trout, Salmo trutta fario, Anisakis, Elbe River basin, Czech Republic

\begin{abstract}
In the years 1999-2002, first studies were carried out on the metazoan parasites of Atlantic salmon (Salmo salar L.) recently reintroduced into the Elbe River drainage system, after more than 50 years after the complete extinction of the Elbe salmon population. A total of six helminth species were recorded from salmon smolts from three streams of the Elbe River basin (Kamenice River, Ještědský and Libočanský Brooks) in North Bohemia, Czech Republic, where S. salar fingerlings have been released since 1998: Gyrodactylus truttae Gläser, 1974, Crepidostomum metoecus Braun, 1900, Diplostomum spathaceum (Rudolphi, 1819) metacercariae, Raphidascaris acus (Bloch, 1799) adults and encapsulated larvae, Cystidicoloides ephemeridarum (Linstow, 1872), and Neoechinorhynchus rutili (Müller, 1780). Except for D. spathaceum, all these freshwater parasites have been received from the helminth fauna of the co-habiting brown trout (Salmo trutta fario L.). Due to local ecological conditions, the parasite faunae of both salmon and brown trout exhibited distinct qualitative and quantitative differences in the three localities. The finding of G. truttae on $S$. salar represents a new host record. Three helminth parasites of marine origin, the cestodes Eubothrium crassum (Bloch, 1779) and Scolex pleuronectis Müller, 1788 plerocercoids, and the nematode Anisakis simplex (Rudolphi, 1809) larvae were found in the single examined adult $S$. salar from the Kamenice River. New data on the geographical distribution of some nematode parasites of Salmo trutta fario L., Barbatula barbatula (L.) and Anguilla anguilla (L.) are presented.
\end{abstract}

Atlantic salmon (Salmo salar L.) is undoubtedly the most attractive and the most valuable species of European salmonids. Until the 30's of the last century, this anadromous fish regularly occurred in the Elbe River and its tributaries almost in the whole territory of Bohemia (western part of the present Czech Republic); however, after some transverse barriers (overfall dykes and weirs) were built on the Elbe, particularly the locks in Střekov near Ústí nad Labem, and as the result of an enormous water pollution, the Elbe population of salmon completely disappeared (Baruš and Oliva 1995). During recent years, the water quality in the Elbe considerably improved and the river barriers in both Germany and the Czech Republic were modified so that now they are allowing fish migration. Therefore, attempts to reintroduce salmon into the Elbe drainage system, after more than 50 years, were initiated first in Germany (since 1994) and, since the spring of 1998 , also in the basins of the three main tributaries of the Elbe (Rivers Kamenice, Ploučnice and Ohře) in northern Bohemia. Considering the "home stream theory", hatchery-reared salmon fry (from eggs imported from Sweden) were used for restocking. While the first adult migrating salmon in Germany were observed in 1998, in the Czech Republic the first two adult specimens were recorded from the Elbe River near Děčín in 2001
(Vostradovský 2002). Four adult salmon specimens were caught in the Kamenice River in November 2002.

From the ichthyoparasitological point of view, the reintroduction of salmon into the Elbe River basin represented a unique situation to study the re-establishment of the parasite fauna of this fish under specific ecological conditions, particularly in the connection with acquiring some parasites from other salmonids, mainly the common freshwater form of brown trout (Salmo trutta fario L.), and, later, with carrying marine parasites into the freshwater environment of the streams by upstream migrating adult salmon.

The only existing data on the parasites of the original Elbe population of salmon in Bohemia are those by Frič $(1893,1908)$, who reported in upstream migrating salmon several species of metazoan parasites, almost exclusively of marine origin; almost no attention was paid to the parasites of parr or smolt. Data on salmon parasites in other European countries are rather restricted, in recent years these being found largely in the papers of Norwegian authors (e.g., Bristow and Berland 1991a, b, Berland 1993, Bristow 1993, Mo 1993, 1997, Appleby and Mo 1997, Appleby et al. 1997) devoted to the parasite fauna of free-living and cultured salmon, particularly with respect to the pathogenicity of parasites. 
During 1999-2002, samples of Atlantic salmon reintroduced into the three North Bohemian streams, as well as those of brown trout and some other fish species from the same localities, were examined for the presence of metazoan parasites. The results obtained are presented herein.

\section{MATERIALS AND METHODS}

In co-operation with the Czech Angler's Union in Ústí nad Labem, irregular fish samples were taken from the following three main North Bohemian localities where the fingerlings of Atlantic salmon (Salmo salar L.) have been released since 1998: (1) the Kamenice River near Hřensko including its tributary the Bílý Brook; (2) the Ještědský Brook near Stráž pod Ralskem, a tributary of the Ploučnice River; and (3) the Libočanský Brook near Žatec (at the village of Vikletice), a tributary of the Ohře River. All these belong to the Elbe River drainage system (Fig. 1). The fish were collected by electrofishing in the period 1999-2002. Immediately after the transfer of live fish to the laboratory in České Budějovice, these were examined for the presence of metazoan parasites.

The following fishes were examined: Atlantic salmon (Salmo salar L.) smolts 58 specimens (total body length 7-22 cm) (Kamenice R. [6 5 specimens] - 17 October 2000; Ještědský B. [8] - 1 August 2001 and [9] - 18 June 2002; Libočanský B. [10] - 7 June 2000, [14] - 7 August 2001, and [11] - 19 June 2002); brown trout (Salmo trutta fario L.) 61 specimens (8-38 cm) (Kamenice R. [14] - 8 April 1999, [8] 17 October 2000 and [10] - 23 October 2001; Ještědský B. [10] - 1 August 2001 and [5] - 18 June 2002; Libočanský B. [4] - 7 June 2000, [3] - 7 August 2001 and [7] - 19 June 2002); grayling (Thymallus thymallus [L.]) 4 specimens (15$22 \mathrm{~cm}$ ) (Kamenice R. [1] - 17 October 2000; Ještědský B. [3] - 1 August 2001); stone loach (Barbatula barbatula [L.]) 13 specimens (8-13 cm) (Ještědský B. [3] - 1 August 2001; Libočanský B. [4] - 7 August 2001 and [4] - 19 June 2002); bullhead (Cottus gobio L.) 17 specimens $(7-15 \mathrm{~cm})$ (Kamenice R. [3] - 17 October 2000 and [1] - 23 October 2001); European eel (Anguilla anguilla [L.]) 10 specimens (36-80 cm) (Ještědský B. [6] - 1 August 2001 and [3] - 18 June 2002; Libočanský B. [1] - 7 June 2000); brook minnow (Phoxinus phoxinus [L.]) 1 specimen $(12 \mathrm{~cm})$ (Libočanský B. - 19 June 2002); and roach (Rutilus rutilus [L.]) 1 specimen (7 cm) (Libočanský B. - 7 June 2000).

Besides, 10 specimens of salmon fry (total body length $2.5-3.0 \mathrm{~cm}$ ) originating from the fish hatchery in Jablonec, Czech Republic, and 50 similar specimens (length $2.4-2.8 \mathrm{~cm}$ ) produced at the hatchery near Neustadt and Sebnitz, Germany, were examined for the presence of parasites on 5 May 1999 and 9 May 2000, respectively, just before the fry from these two hatcheries were stocked into the North Bohemian streams (basins of the Kamenice, Ploučnice and Ohře Rivers).

In 2002, the second year after the first appearance of adult salmon in the Czech Republic, four large migrating $S$. salar were caught in the Kamenice River on 1 November; one of them (male, total body length $70 \mathrm{~cm}$ ) was examined for parasites.

The recovered helminth parasites were washed in physiological saline and then fixed in hot $4 \%$ formaldehyde solution.

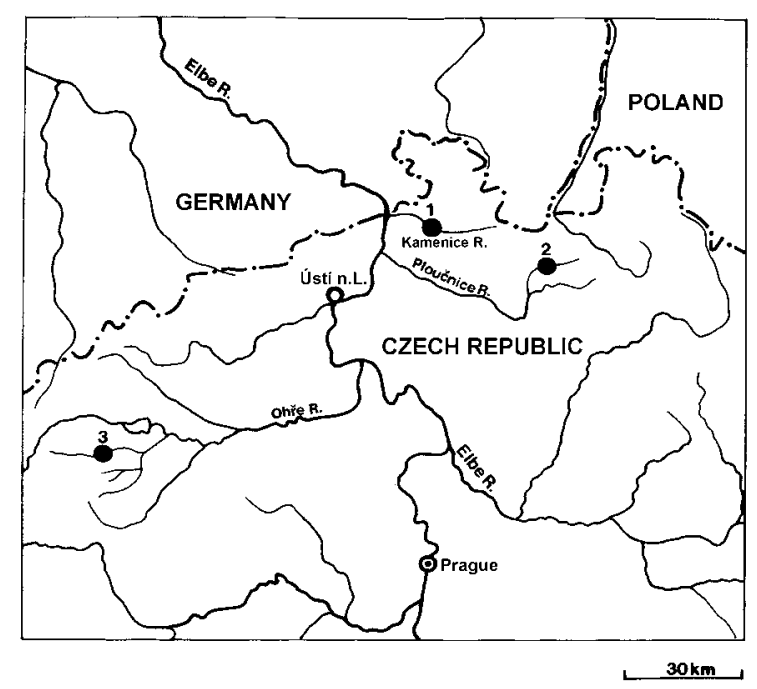

Fig. 1. Map of sampling sites. 1 - Kamenice River; 2 - Ještědský Brook; 3 - Libočanský Brook.

For light microscopical examination, the nematodes were cleared with glycerine, whereas the cestodes, trematodes and acanthocephalans were stained in carmine, dehydrated through an ethanol series and mounted in Canada balsam as permanent slides. Drawings were made with the aid of a Zeiss drawing attachment. The specimens have been deposited in the Helminthological Collection of the Institute of Parasitology, ASCR, in České Budějovice. Specimens used for scanning electron microscopy (SEM) were postfixed in $1 \%$ osmium tetroxide, dehydrated through an alcohol series, critical point dried and sputter-coated with gold; they were examined using a JEOL JSM-6300 scanning electron microscope at an accelerating voltage of $15 \mathrm{kV}$. The scientific names of fishes are according to Froese and Pauly (2001). All measurements are in micrometres unless otherwise stated.

\section{RESULTS}

\section{Parasitological examination of Salmo salar fry}

No metazoan parasites were recorded from salmon fry, originating from two fish hatcheries, before their release into the North Bohemian streams.

\section{Parasites of Salmo salar smolts}

A total of six freshwater helminth species were recorded from salmon smolts from the three North Bohemian localities: Monogenea: Gyrodactylus truttae Gläser, 1974 (fins); Trematoda: Crepidostomum metoecus Braun, 1900 (intestine) and Diplostomum spathaceum (Rudolphi, 1819) metacercariae (lens of eye); Nematoda: Raphidascaris acus (Bloch, 1779) adults (intestine) and encapsulated larvae (walls of digestive tract) and Cystidicoloides ephemeridarum (Linstow, 1872) (stomach); and Acanthocephala: Neoechinorhynchus rutili (Müller, 1780) (intestine). These species were also found in S. trutta fario, and some of them in other fish species, in the localities under study. 
Table 1. Survey of helminth parasites of Salmo salar smolts in three North Bohemian localities.

\begin{tabular}{|c|c|c|c|c|c|c|}
\hline \multirow[b]{2}{*}{ Parasite } & \multicolumn{2}{|c|}{ Kamenice River } & \multicolumn{2}{|c|}{ Ještědský Brook } & \multicolumn{2}{|c|}{ Libočanský Brook } \\
\hline & $\begin{array}{c}\text { Prevalence } \\
\text { (no. infected/ } \\
\text { no. examined) }\end{array}$ & $\begin{array}{c}\text { Intensity } \\
\text { mean (range) }\end{array}$ & $\begin{array}{c}\text { Prevalence } \\
\text { (no. infected/ } \\
\text { no. examined) }\end{array}$ & $\begin{array}{c}\text { Intensity } \\
\text { mean (range) }\end{array}$ & $\begin{array}{c}\text { Prevalence } \\
\text { (no. infected/ } \\
\text { no. examined) }\end{array}$ & $\begin{array}{c}\text { Intensity } \\
\text { mean (range) }\end{array}$ \\
\hline G. truttae & $50 \%(3 / 6)$ & $1(1)$ & - & - & $11 \%(4 / 35)$ & $2(1-2)$ \\
\hline C. metoecus & - & - & $6 \%(4 / 17)$ & $5(5)$ & - & - \\
\hline D. spathaceum larv. & - & - & $6 \%(1 / 17)$ & $1(1)$ & - & - \\
\hline R. acus & - & - & - & - & $6 \%(2 / 35)$ & $1(1)$ \\
\hline $\begin{array}{l}\text { R. acus larv. } \\
\text { (encapsulated) }\end{array}$ & $33 \%(2 / 6)$ & $1(1)$ & $6 \%(1 / 17)$ & $7(7)$ & $9 \%(3 / 35)$ & $3(1-7)$ \\
\hline C. ephemeridarum & - & - & $82 \%(14 / 17)$ & $20(1-60)$ & $3 \%(1 / 35)$ & $1(1)$ \\
\hline N. rutili & $33 \%(2 / 6)$ & $1(1)$ & - & - & - & - \\
\hline
\end{tabular}

Table 2. Survey of helminth parasites of Salmo trutta fario in three North Bohemian localities.

\begin{tabular}{|c|c|c|c|c|c|c|}
\hline \multirow[b]{2}{*}{ Parasite } & \multicolumn{2}{|c|}{ Kamenice River } & \multicolumn{2}{|c|}{ Ještědský Brook } & \multicolumn{2}{|c|}{ Libočanský Brook } \\
\hline & $\begin{array}{c}\text { Prevalence } \\
\text { (no. infected/ } \\
\text { no. examined) }\end{array}$ & $\begin{array}{c}\text { Intensity } \\
\text { mean (range) }\end{array}$ & $\begin{array}{c}\text { Prevalence } \\
\text { (no. infected/ } \\
\text { no. examined) }\end{array}$ & $\begin{array}{c}\text { Intensity } \\
\text { mean (range) }\end{array}$ & $\begin{array}{l}\text { Prevalence } \\
\text { (no. infected/ } \\
\text { no. examined) }\end{array}$ & $\begin{array}{c}\text { Intensity } \\
\text { mean (range) }\end{array}$ \\
\hline G. truttae & $97 \%(31 / 32)$ & $10(1-53)$ & $27 \%(4 / 15)$ & $3(1-6)$ & $29 \%(4 / 14)$ & $3(1-6)$ \\
\hline P. longicollis & $16 \%(5 / 32)$ & $3(1-5)$ & - & - & - & - \\
\hline C. farionis & $50 \%(16 / 32)$ & $4(1-12)$ & $7 \%(1 / 15)$ & $1(1)$ & - & - \\
\hline C. metoecus & - & - & $40 \%(6 / 15)$ & $10(1-30)$ & $14 \%(2 / 14)$ & $1(1)$ \\
\hline D. spathaceum larv. & - & - & $7 \%(1 / 15)$ & $1(1)$ & - & - \\
\hline T. clavata larv. & - & - & $7 \%(1 / 15)$ & $3(3)$ & - & - \\
\hline R. acus & $31 \%(10 / 32)$ & $5(1-21)$ & $13 \%(2 / 15)$ & $3(1-4)$ & $57 \%(8 / 14)$ & $2(1-3)$ \\
\hline $\begin{array}{l}\text { R. acus } \\
\quad \text { (encapsulated) }\end{array}$ & - & - & - & - & $36 \%(5 / 14)$ & $4(1-10)$ \\
\hline C. truttae & $6 \%(2 / 32)$ & $62(10-114)$ & $7 \%(1 / 15)$ & $7(7)$ & - & - \\
\hline C. ephemeridarum & $28 \%(9 / 32)$ & $8(1-40)$ & $87 \%(13 / 15)$ & $25(3-62)$ & - & - \\
\hline E. truttae & $34 \%(11 / 32)$ & $2(1-5)$ & - & - & - & - \\
\hline N. rutili & $66 \%(21 / 32)$ & $5(1-17)$ & $7 \%(1 / 15)$ & $1(1)$ & - & - \\
\hline
\end{tabular}

Table 1 indicates that there are distinct qualitative and quantitative differences in the helminth fauna of salmon smolts in these different localities. Most parasites in smolts occurred at low prevalence and intensity, only the $C$. ephemeridarum infection was high in the Ještědský Brook (prevalence $82 \%$, intensity up to 60 nematodes), whereas it was rare or absent in smolts in the other two localities.

\section{Parasites of migrating adult Salmo salar}

The following three helminth species were found in the only adult $S$. salar examined: Cestoda: Eubothrium crassum (Bloch, 1779) juv. (8 specimens) (anterior part of intestine near pyloric caeca); Scolex pleuronectis Müller, 1788 larvae (3) (middle part of intestine); and Nematoda: Anisakis simplex (Rudolphi, 1809) larvae (9) (encapsulated on surface of intestine, pyloric caeca and liver). All of them are marine parasites.

\section{Parasites of Salmo trutta fario}

In the three localities under study, a total of 11 helminth species were recorded from brown trout: Monogenea: Gyrodactylus truttae (fins, rarely gills); Cestoda: Proteocephalus longicollis (Zeder, 1800) (intestine);
Trematoda: Crepidostomum farionis (Müller, 1780) (intestine), Crepidostomum metoecus (intestine, pyloric caeca), Diplostomum spathaceum (Rudolphi, 1819) metacercariae (lens of eye), Tylodelphys clavata (Nordmann, 1832) metacercariae (humour of eye); Nematoda: Raphidascaris acus adults (intestine) and encapsulated larvae (walls of digestive tract), Cucullanus truttae Fabricius, 1794 (intestine, pyloric caeca), Cystidicoloides ephemeridarum (stomach); Acanthocephala: Echinorhynchus truttae Schrank, 1788 (intestine) and Neoechinorhynchus rutili (intestine). All these are typical freshwater parasites.

Table 2 shows distinct qualitative and quantitative differences in the helminth fauna of brown trout in the three localities in question.

Helminth parasites recorded from other fish species

Only a few specimens of other fish species from the respective localities were examined for parasites:

Kamenice River: Thymallus thymallus - 2 specimens of Tetraonchus borealis (Olsson, 1893) (Monogenea) (gills) on 1 fish examined. Cottus gobio - 3 Echinorhynchus truttae (intestine) in 1 of 3 fish. 

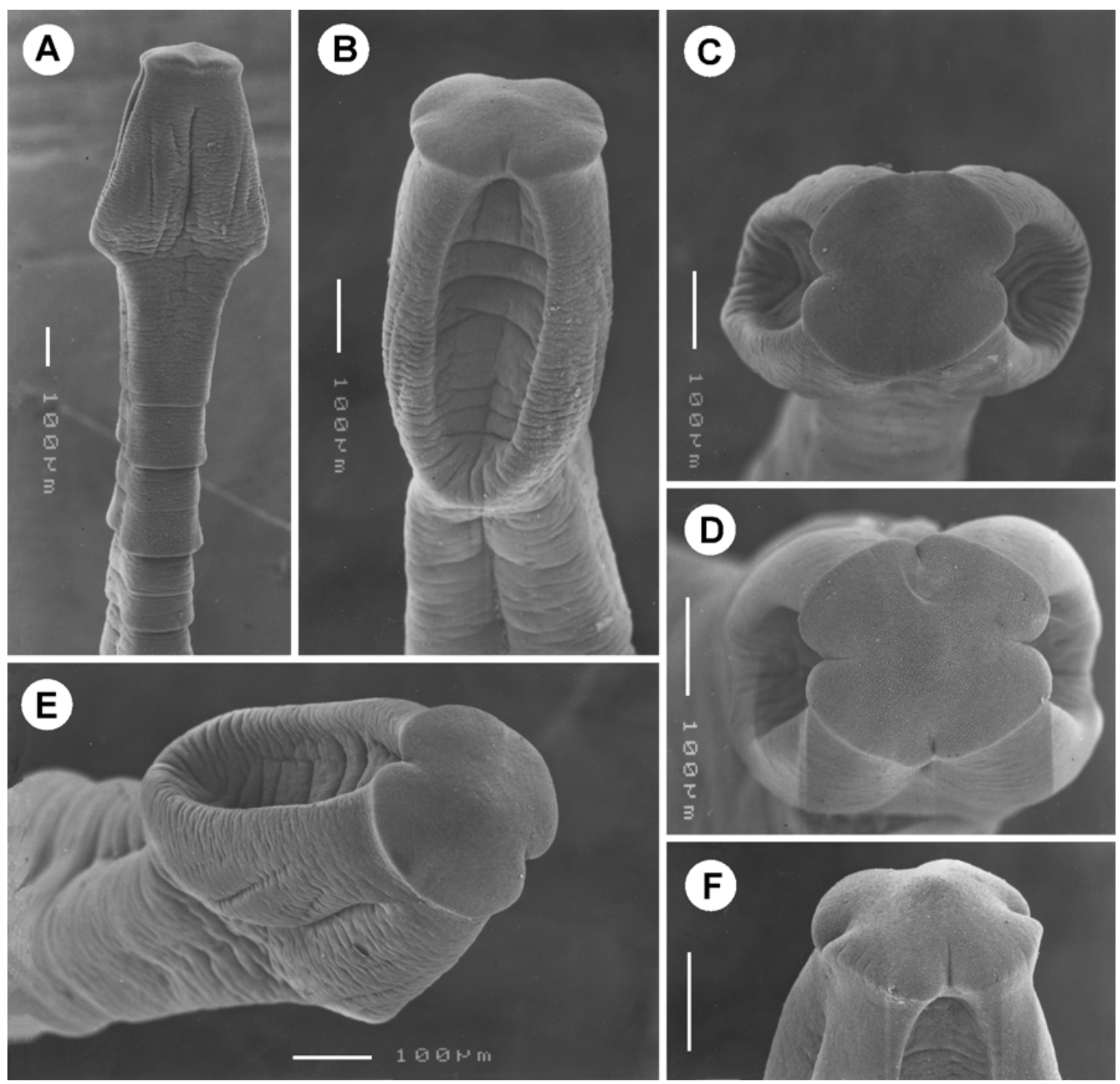

Fig. 2. Eubothrium crassum (Bloch, 1779) juv. from Salmo salar, scanning electron micrographs. A - anterior end of body, lateral view; B - scolex, dorsoventral view; C - apical disc of scolex with indistinct lateral grooves, apical view; D - apical disc of another specimen with distinct lateral grooves, apical view; $\mathbf{E}$ - scolex of specimen with indistinct lateral grooves on apical disc, subapical view; $\mathbf{F}$ - apical disc with distinct lateral grooves, sublateral view (scale bar $=100 \mu \mathrm{m}$ ).

Ještědský Brook: Thymallus thymallus - 1 specimen of Crepidostomum metoecus (intestine) in 1 of 3 fish examined and 2 Diplostomum spathaceum metacercariae (lens of eye) in 1 of 3 . Barbatula barbatula all 3 examined specimens infected with 4 helminth species: Crepidostomum metoecus (intestine) (intensity 8-35), Apatemon cobitidis (Linstow, 1890) metacercariae (Trematoda) (abdominal cavity) (intensity 834), Raphidascaris acus larvae (liver) (intensity about 100-150) and Rhabdochona ergensi Moravec, 1968 (Nematoda) (intestine) (intensity 4-16); in addition, 1 of 3 fish harboured Cystidicoloides ephemeridarum larvae (stomach) (intensity 12). Anguilla anguilla - Crepidostomum metoecus (intestine) (in 1 of 9 fish examined; intensity 1), Raphidascaris acus (intestine) (in 1 of 9;
1), Paraquimperia tenerrima (Linstow, 1878) (Nematoda) (intestine) (in 5 of 9;1-14), Cucullanus truttae (intestine) (in 3 of 9; 1-6), Camallanus lacustris (Zoega, 1776) (Nematoda) (intestine) (in 1 of 9; 1), Anguillicola crassus Kuwahara et al., 1974 (Nematoda) (swimbladder) (in 2 of 9;3-8), and Neoechinorhynchus rutili (intestine) (in 2 of $9 ; 1-2$ ).

Libočanský Brook: Barbatula barbatula - Proteocephalus sagittus (Grimm, 1872) (Cestoda) (intestine) (in 1 of 10 fish examined; intensity 1), Apatemon cobitidis metacercariae (abdominal cavity) (in 2 of 10; 1-20), and Raphidascaris acus larvae (in all fish examined; 21-150 [mean 72]). No parasites were found in 14 Cottus gobio, 1 Phoxinus phoxinus and 1 Rutilus rutilus. 

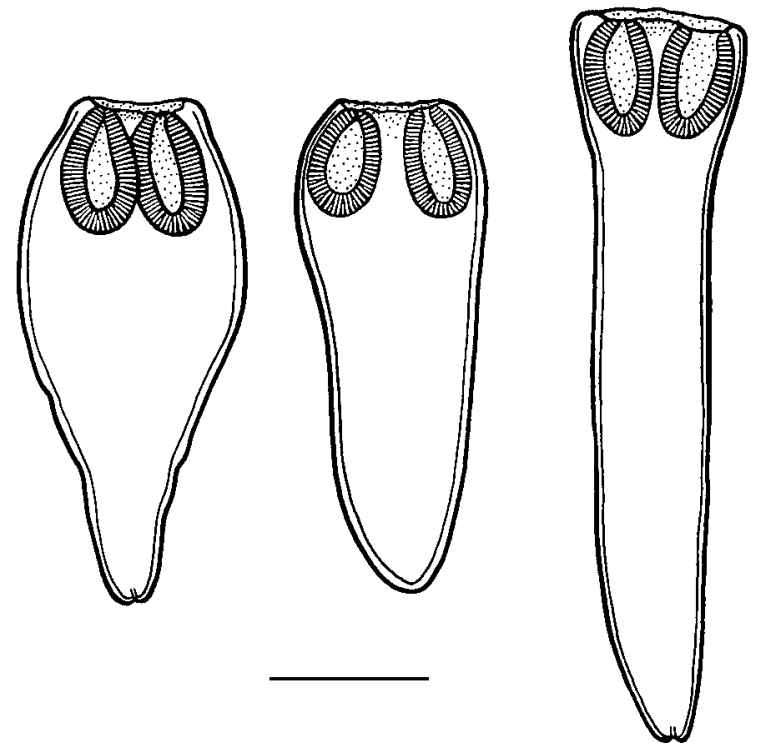

Fig. 3. Variability of body shape of Scolex pleuronectis Müller, 1788 plerocercoids from Salmo salar. Scale bar $=100$ $\mu \mathrm{m}$.

\section{Morphometrical data on helminth parasites of marine origin recorded from adult $S$. salar}

Family T r i a e n o p h o r i d a e Lönnberg, 1889 Eubothrium crassum (Bloch, 1779) juv.

Length of body 6,433-11,628, maximum width 490625. Scolex 734-816 long and 476-585 wide in lateral view; apical disc 95 long and 272-326 wide, with four grooves (dorsal, ventral and two lateral; latter indistinct in one specimen - see Fig. 2 C, E) upon apical view; bothria 517-625 long. Strobila segmented, segments at its middle part 95-204 long and 422-625 wide. Genital organs not yet developed.

Family P h y 11 o b o th ri i d a e Braun, 1900 Scolex pleuronectis Müller, 1788 plerocercoids Fig. 3

Body short, from pear-shaped to elongate, 340-476 long and 122-150 wide, with withdrawn anterior end. Apical sucker indistinct. Four oval bothridia, 84 long and 48-54 wide, present on anterior end of body. No anlagen of genital organs present.

Scolex Müller, 1787 is a larval collective name.

Family A n i s a k i d a e Railliet et Henry, 1912 Anisakis simplex (Rudolphi, 1809) third-stage larvae

Fig. 4

Body length 18,904-23,514, maximum width 313408. Cuticle with fine transverse striation. Ventral larval tooth 6-9 long; length of anlagen of lips 39-45. Excretory pore situated just below larval tooth. Oesophagus 1,782-2,176 long, 68-122 wide; nerve ring 299340 from anterior extremity. Ventriculus fairly long, 707-898, width 136-245. Tail conical, 95-122 long including terminal cuticular spike; latter 15-21 long.

\section{DISCUSSION}

The only available data on the parasites of Atlantic salmon (S. salar) from the territory of the present Czech Republic, before the extinction of the original population of this fish from the Elbe River basin, are those published by Frič $(1893,1908)$. He reported twelve species of metazoan parasites of adult salmon, the actual species or generic appurtenance of some of which is, however, uncertain: Bothriocephalus infundibuliformis Rud. (= Eubothrium crassum), Tetrarrhynchus macrobothrius Sieb. larv. (= Tentacularia coryphaenae Bosc, 1997; or Nybelinia sp. ? - see Scholz 1989), Scolex polymorphus Rud. larv. (= S. pleuronectis), Distomum varicum Zed. (= Derogenes varicus [Müller, 1784]), Distomum appendiculatum Rud. (= Hemiurus appendiculatus [Rudolphi, 1802]), Agamonema capsularia Dies. larv. (= Anisakis simplex), Ascaris clavata Rud. (= Hysterothylacium aduncum gadi [Müller, 1776]), Echinorrhynchus pachysomus Creplin (= Echinorhynchus salmonis Müller, 1780), Piscicola geometra (Linnaeus, 1761), Lernaeopoda salmonea Blainw. (= Salmincola salmoneus [Linnaeus, 1758]), and Argulus coregoni Thorell, 1864. Except for P. geometra and $A$. coregoni, all these are marine parasites (E. crassum may also occur in fresh waters). Frič (1893) mentions that only Scolex pleuronectis (as S. polymorphus), Derogenes varicus (as D. varicum) and Hysterothylacium aduncum gadi (as A. clavata) were found in salmon parr; no freshwater parasites were reported by him from smolts.

Since the salmon eggs imported from Sweden have been used as a source for salmon reintroduction both in Germany and the Czech Republic, the risk of a contemporary introduction of any metazoan parasites was minimal. Results of the present study have indicated that no parasites were acquired by salmon fry in the conditions of fish hatcheries before being released into the streams. Therefore, it could be expected that all parasites infecting the salmon smolts originate from the parasite faunas of other local fish species sharing the same environment with salmon, in particular the brown trout ( $S$. trutta fario).

Results of the present study show clearly that the helminth fauna of salmon smolts was mainly formed by the species more or less typical of salmonids (Gyrodactylus truttae, Crepidostomum metoecus, Raphidascaris acus, Cystidicoloides ephemeridarum, Neoechinorhynchus rutili), which were the most frequent parasites of brown trout in these localities (cf. Tables 1 and 2). The apparent qualitative and quantitative differences in the helminth fauna of brown trout in the three localities under investigation (Table 2) are also reflected in the composition of the helminth fauna of salmon smolts (Table 1). As compared to that of brown trout, the fauna of helminth parasites of salmon smolts is poorer in species and the infection is lower; apparently, these differences are mainly associated with the body size of 

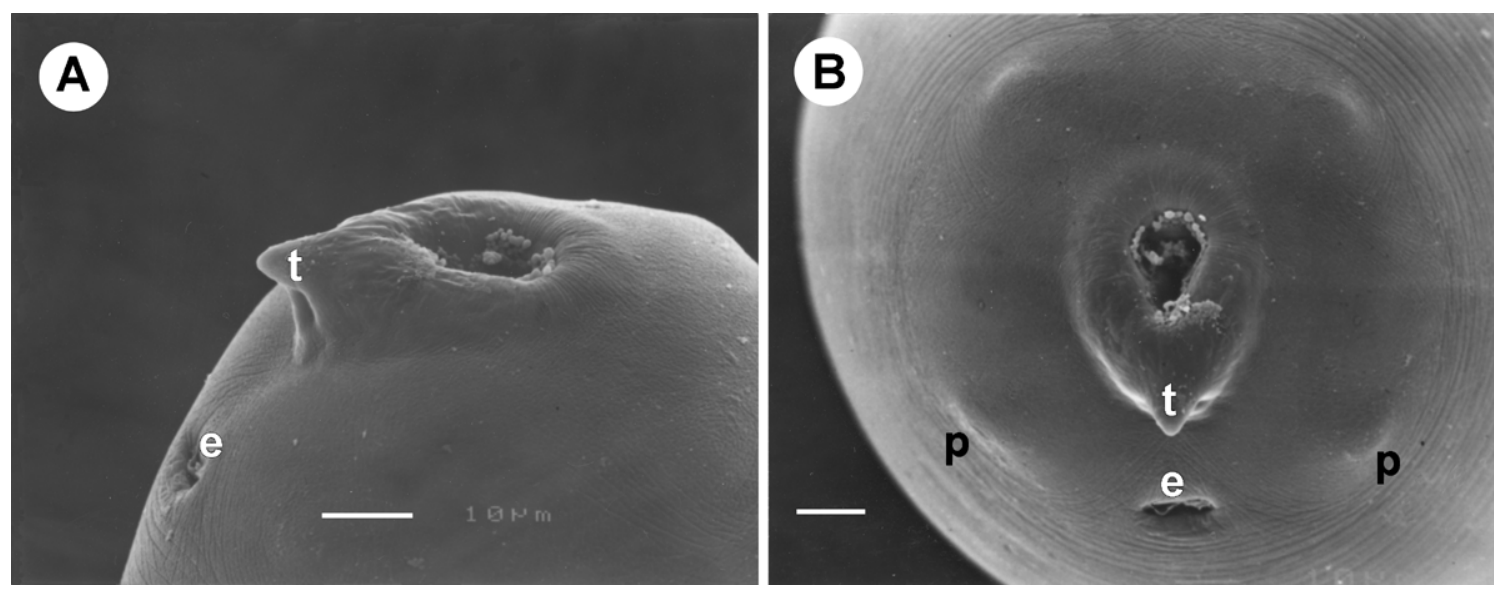

Fig. 4. Cephalic end of Anisakis simplex (Rudolphi, 1809) third-stage larva from Salmo salar, scanning electron micrographs. $\mathbf{A}$ - lateral view; $\mathbf{B}$ - apical view (scale bar $=10 \mu \mathrm{m}$ ). Abbreviations: $\mathrm{e}$ - excretory pore; $\mathrm{p}$ - cephalic papillae; $\mathrm{t}-\mathrm{ventral}$ cephalic tooth.

the host (most trout were distinctly larger and older) and differences in the food choice in these two salmonid species. Generally, there is an increase of helminth infections with the increasing body size and age of fish (Moravec 1994). In the case of the nematode Cucullanus truttae, this occurs only in larger specimens of trout (longer than $22 \mathrm{~cm}$ ) which are able to swallow the lampreys serving as intermediate hosts (Moravec 1980), and, therefore, C. truttae could not be found in smaller salmon smolts.

In addition to adult helminth parasites, salmon smolts were found to harbour two species of larvae, $R$. acus (encapsulated larvae) and D. spathaceum, serving thus as intermediate hosts for these parasites and a possible source of infection to the definitive hosts (larger salmonids in the former and fish-eating birds in the latter).

Several, hardly distinguishable species of the monogenean genus Gyrodactylus Nordmann, 1832 have been reported from salmonids in Europe, of which G. salaris Malmberg, 1957 is known as a serious pathogen of $S$. salar in Norway (e.g., Bakke et al. 1992, Shinn et al. 1995). The present data show that $G$. truttae, a common parasite of $S$. trutta fario, can infect $S$. salar smolts under natural conditions, even though the rate of infection on the latter was found to be lower (cf. Tables 1 and 2). The finding of this parasite on $S$. salar represents a new host record.

None of the other co-occurring fish species in the three localities in question were found to have a substantial influence on the formation of the helminth fauna of salmon smolts. Thymallus thymallus, Barbatula barbatula and Cottus gobio served as only subsidiary definitive hosts for C. metoecus and E. truttae, whereas Anguilla anguilla probably served mainly as a postcyclic host to $C$. metoecus and $N$. rutili, as well as to $C$. truttae, a parasite of trout not recorded from S. salar. Barbatula barbatula was found to be an important inter- mediate or paratenic host to $R$. acus and C. ephemeridarum.

All three helminth species now recorded from adult salmon were already reported from this fish by Frič (1893) from the Elbe River. He mentioned that large specimens (up to $173 \mathrm{~cm}$ long) of the tapeworm E. crassum occurred in salmon mainly in March, whereas usually only small specimens were found in the following months. He also mentioned that salmon acquired the infection with $E$. crassum in the sea and, if salmon stayed in fresh water for a longer period, these parasites disappeared. The two recorded larval stages are frequent parasites of various species of marine fishes; the definitive hosts of Scolex pleuronectis are sharks and rays, whereas those of Anisakis simplex are marine mammals (cetaceans and pinnipeds). Because only one adult salmon has so far been examined, it can be expected that several other helminth species will be introduced into the streams in the Czech Republic and Germany, including species important from the view of public health. The present study again confirms, after more than a hundred of years, the occurrence of Anisakis simplex larvae, the agents of a serious disease in humans, in wild fish in the Czech Republic.

Besides data on the parasites of $S$. salar, this study presents some new important observations on fish nematodes in other host species. Rhabdochona ergensi, a specific parasite of loaches, is for the first time reported from the Elbe River basin (previously known only from the basins of the Baltic, Black and Aral Seas, from Finland and from some endemic basins in India and Afghanistan - see Moravec 1994). Cucullanus truttae found in brown trout and eel is for the first time reported from the region of North Bohemia; in the Czech Republic, it was previously known only from three localities in South and West Bohemia (Moravec 1994); the findings of this parasite in fishes indicate the 
occurrence of presently endangered and rarely occurring lampreys in the same localities. Paraquimperia tenerrima and the highly pathogenic, introduced Anguillicola crassus, specific parasites of eels, have not previously been reported from the Ploučnice River drainage system (Moravec 2001).

Acknowledgements. The author's thanks are due to Jan Šmíd from the Czech Fishermen's Union in Ústí nad Labem for permission to carry out ichthyoparasitological investigations in the three localities where salmon were reintroduced, as well as for his help in collecting fishes, and to the management of the National Park Czech Switzerland (České Švýcarsko) in Krásná Lípa for the permission to carry out investigations in the Kamenice River in the National Park. The author is also grateful to the staff of the Laboratory of Electron Microscopy of the Institute of Parasitology, ASCR, in České Budějovice and to Irena Husáková and Blanka Škoríková from the Department of Helminthology of the same Institute for their technical assistance. This study was supported by the grant no. 524/00/0267 from the Grant Agency of the Czech Republic.

\section{REFERENCES}

APPLEBY C., MO T.A. 1997: Population dynamics of Gyrodactylus salaris (Monogenea) infecting Atlantic salmon, Salmo salar, parr in the river Batnfjordselva, Norway. J. Parasitol. 83: 23-30.

APPLEBY C., MO T.A., AASE I.-L. 1997: The effect of Gyrodactylus salaris (Monogenea) on the epidermis of Atlantic salmon, Salmo salar, parr in the river Batnfjordselva, Norway. J. Parasitol. 83: 1173-1174.

BAKKE T.A., HARRIS P.D., JANSEN P.A., HANSEN L.P. 1992: Host specificity and dispersal strategy in gyrodactylid monogeneans, with particular reference to Gyrodactylus salaris (Platyhelminthes, Monogenea). Dis. Aquat. Org. 13: 63-74.

BARUŠ V., OLIVA O. (Eds.) 1995: [Cyclostomes Petromyzontiformes and Fishes (1) Osteichthyes. Fauna of the Czech and Slovak Republics 28/1.] Academia, Praha, 623 pp. (In Czech.)

BERLAND B. 1993: Salmon lice on wild salmon (Salmo salar L.) in western Norway. In: G.A. Boxshall and D. Defaye (Eds.), Pathogens of Wild and Farmed Fish: Sea Lice. Ellis Horwood series in Aquaculture and Fisheries Support. Ellis Horwood, New York, pp. 179-187.

BRISTOW G.A. 1993: Parasites of Norwegian freshwater salmonids and interactions with farmed salmon - a review. Fish. Res. 17: 219-227.

BRISTOW G.A., BERLAND B. 1991a: A report on some metazoan parasites of wild marine salmon (Salmo salar L.) from the west coast of Norway with comments on their interactions with farmed salmon. Aquaculture 98: 311318.

BRISTOW G.A., BERLAND B. 1991b: The effect of long term, low level Eubothrium sp. (Cestoda: Pseudophyllidea) infection on growth in farmed salmon (Salmo salar L.). Aquaculture 98: 325-330.
FRIČ A. 1893: [Salmon of the Elbe, a Biological and Anatomical Study.] Author's edition, Praha, 106 pp. (In Czech.)

FRIČ A. 1908: [Czech Fishes and Their Parasites.] Author's edition, Praha, 78 pp. (In Czech.)

FROESE R., PAULY D. (Eds.) 2001: FishBase. World Wide Web electronic publication, www.fishbase.org, 02 January 2002.

MO T.A. 1993: Seasonal variations of the opisthaptoral hard parts of Gyrodactylus derjavini Mikailov, 1975 (Monogenea: Gyrodactylidae) on brown trout Salmo trutta L. parr and Atlantic salmon S. salar L. parr in the River Sandvikselva, Norway. Syst. Parasitol. 26: 225-231.

MO T.A. 1997: Seasonal occurrence of Gyrodactylus derjavini (Monogenea) on brown trout, Salmo trutta, and Atlantic salmon, S. salar, in the Sandvikselva River, Norway. J. Parasitol. 83: 1025-1029.

MORAVEC F. 1980: Biology of Cucullanus truttae (Nematoda) in a trout stream. Folia Parasitol. 27: 217-226.

MORAVEC F. 1994: Parasitic Nematodes of Freshwater Fishes of Europe. Academia and Kluwer Academic Publishers, Praha and Dordrecht, $473 \mathrm{pp}$.

MORAVEC F. 2001: Checklist of the Metazoan Parasites of Fishes of the Czech Republic and the Slovak Republic (1873-2000). Academia, Praha, 168 pp.

SCHOLZ T. 1989: Amphilinida and Cestoda, parasites of fish in Czechoslovakia. Acta Sci. Nat. Brno 23: 1-56.

SHINN A.P., SOMMERVILLE C., GIBSON D.I. 1995: Distribution and characterization of species of Gyrodactylus Nordmann, 1832 (Monogenea) parasitizing salmonids in the UK, and their discrimination from $G$. salaris Malmberg, 1957. J. Nat. Hist. 29: 1383-1402.

VOSTRADOVSKÝ J. 2002: [Adult salmon returned to the Elbe River in Bohemia already in 2001.] Rybářství 2002 (4): 198. (In Czech.) 